\title{
Identifikasi Batuan Megalit Terpendam Menggunakan Metode Geomagnet di Situs Megalitik Tadulako Kecamatan Lore Tengah Kabupaten Poso
}

\section{Identification of Undersurface Megalite Rock Using Geomagnet Method in Megalitic Site of Tadulako in Central Lore District Poso Regency}

\author{
Bernald Marco Soro $^{1 *}$, Sandra Sandra ${ }^{1}$, Sitti Rugayya ${ }^{1}$ dan Badaruddin ${ }^{1}$ \\ ${ }^{1}$ Lab. Fisika Bumi dan Kelautan Jur. Fisika Fakultas MIPA, Universitas Tadulako
}

\begin{abstract}
The research on identification of buried megalithic rocks used the geomagnetic method have been conducted at the Tadulako Megalithic Site in Central Lore District, Poso Regency. This study aims to interpret the position and depth of the existence of buried megalithic rocks. The geomagnetic method is used to obtain contours that describe the intensity distribution of the magnetic field below the surface. Data processing is done by using daily correction data and IGRF correction to obtain total magnetic anomalies. Interpretation of magnetic data is done by forward modeling 2D using GM-SYS software which is quite effective for determining position and depth based on rock susceptibility values. The results obtained from the 4 trajectories show the position of the presence of subsurface granite igneous rocks which are thought to be megalithic rocks in the northwest, west and southeast of the study site. The susceptibility value of rocks obtained is 0.05 SI which is at a depth of 11-72 MBSL.
\end{abstract}

Keywords: Magnetic Anomaly, Megalithic Rock, Rock Susceptibility

\begin{abstract}
ABSTRAK
Penelitian tentang identifikasi batuan megalit terpendam menggunakan metode geomagnet telah dilakukan di Situs Megalitik Tadulako Kecamatan Lore Tengah Kabupaten Poso. Penelitian ini bertujuan untuk menginterpretasi posisi dan kedalaman keberadaan batuan megalit terpendam. Pengambilan data dengan menggunakan metode geomagnet akan memperoleh kontur yang menggambarkan distribusi intensitas medan magnetik di bawah permukaan. Pengolahan data dilakukan dengan koreksi harian dan koreksi IGRF, sehingga diperoleh anomali magnetik total. Interpretasi data magnetik dilakukan dengan pemodelan kedepan 2D menggunakan software GM-SYS yang efektif untuk menentukan posisi dan kedalaman berdasarkan nilai suseptibilitas batuan. Hasil yang diperoleh dari ke 4 lintasan menunjukkan posisi keberadaan batuan beku granit di bawah permukaan yang diduga sebagai batuan megalit berada pada arah Barat Laut, Barat, dan Tenggara lokasi penelitian, dengan nilai suseptibilitas batuan 0,05 SI yang berada pada kedalaman 11-72 $\mathrm{m}$ bmt.
\end{abstract}

Kata Kunci: Anomali Magnetik, Batuan Megalit,Suseptibilitas Batuan

Corresponding Author : bernaldmarco95@gmail.com (ph/fax: +62-82271579812) 


\section{LATAR BELAKANG}

Megalit adalah batu besar yang digunakan untuk membangun struktur atau monumen. Megalit berasal dari Bahasa Yunani, megas berarti besar, dan lithos berarti batu. Megalitik adalah struktur yang dibuat dari batu besar. Kebudayaan Megalitikum bukanlah suatu zaman yang berkembang tersendiri, melainkan suatu hasil budaya yang timbul pada zaman Neolitikum dan berkembang pesat pada zaman logam. Contoh hasil kebudayaan Megalitikum adalah kapak persegi, kapak lonjong, menhir, dolmen, kubur batu, waruga, sarkofagus, punden berundak (Samantho, 2011).

Tinggalan kebudayaan Megalitikum di Lore Tengah terdiri dari 4 jenis, yaitu patung berbentuk manusia, kalamba, tutuna (merupakan penutup kalamba) dan batu dakon yang bentuknya tidak beraturan. Kondisi tinggalan megalitik tersebut saat ini terlihat telah mengalami proses kerusakan dan pelapukan, namun data pasti tentang kondisi kerusakan tersebut belum pernah dilaporkan. Demikian juga upaya konservasi belum dilakukan. Berdasarkan analisis petrografi yang dilakukan tentang kajian konservasi tinggalan megalitik di Lore Tengah, Sulawesi Tengah menunjukan bahwa jenis batuan tinggalan megalitik berupa biotit granit dengan kandungan mineral yang terdiri dari feldspar (plagioklas dan K-feldspar), kuarsa, biotit dan mineral opak (Swastikawati dkk., 2014).

Situs Megalitik Tadulako terletak di Desa Doda, Kecamatan Lore Tengah, Kabupaten Poso. Situs ini memiliki sebaran peninggalan megalitik yang ditaksir berusia sekitar 2000 tahun sebelum masehi berupa benda-benda megalit yang bentuknya beragam yang tersebar di atas permukaan tanah dan diduga masih ada yang terpendam di bawah permukaan tanah. Berdasarkan informasi Peta Geologi Lembar Poso (Simandjuntak dkk., 1997), area Situs Megalitik Tadulako berada dalam Endapan Danau. Endapan Danau tersusun oleh lempung, lanau, pasir, dan kerikil (Gambar 1). Untuk mengidentifikasi keberadaan batuan megalit di bawah permukaan maka dilakukan penelitian. Salah satu metode geofisika yang dapat digunakan adalah metode geomagnet. Metode geomagnet didasarkan pada pengukuran variasi intensitas medan magnet di permukaan bumi yang disebabkan oleh adanya distribusi benda termagnetisasi di bawah permukaan bumi (suseptibilitas magnetik). Benda-benda megalitik memiliki kontras suseptibilitas dengan batuan di sekitarnya sehingga memungkinkan untuk dideteksi dengan metode geomagnet. 


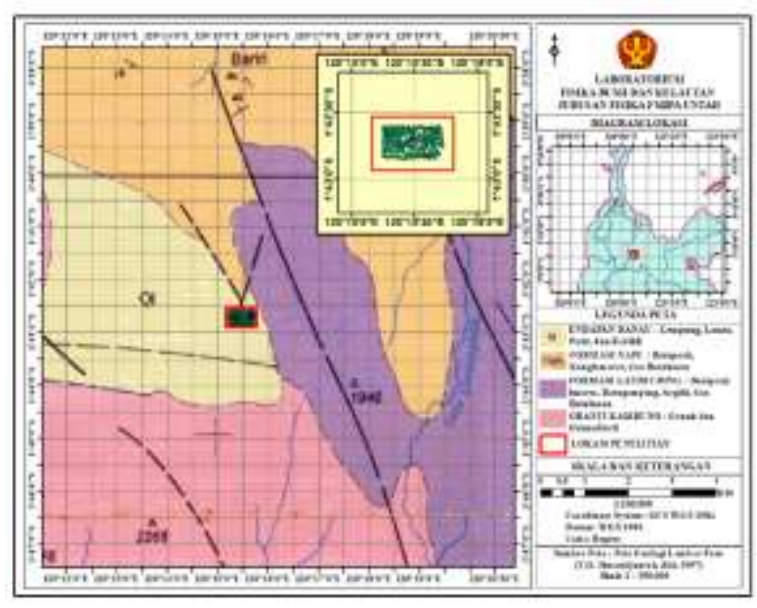

Gambar 1 Peta Geologi Lokasi Penelitian

Penelitian tentang batuan megalit sebelumnya telah dilakukan oleh Baso (2013), tentang Identifikasi Benda-Benda Megalitik Di Situs Megalitik Pokekea Kecamatan Lore Tengah Kabupaten Poso dan Yusuf. M (2017), tentang Identifikasi Benda-Benda Megalit Dengan Menggunakan Metode Geomagnet di Situs Pokekea Kecamatan Lore Tengah Kabupaten Poso. Hasil penelitian Baso, mengatakan bahwa masih terdapat batuan megalit yang terpendam di bawah permukaan tanah sedangkan Yusuf, memperoleh indikasi keberadaan batuan megalit pada kedalaman 85 hingga $114 \mathrm{~m}$ bmt. Oleh karena itu, penelitian ini dilakukan dengan mengukur area lain dari penelitian sebelumnya dengan cakupan yang lebih baik menggunakan metode geomagnet, dan dilakukan interpretasi data magnetik yaitu pemodelan kedepan 2D menggunakan software GM-SYS yang efektif dan dapat menentukan posisi dan kedalaman berdasarkan nilai suseptibilitas batuan.

Metode geomagnet adalah salah satu metode geofisika yang memanfaatkan sifat kemagnetan bumi. Penggunaan metode geomagnet akan memperoleh kontur yang menggambarkan distribusi suseptibilitas batuan di bawah permukaan pada arah horizontal. Dalam survei metode geomagnet yang menjadi target dari pengukuran adalah variasi medan magnetik yang terukur di permukaan (anomali magnetik). Secara garis besar anomali medan magnetik disebabkan oleh medan magnetik remanen dan medan magnetik induksi (Soemantri, 2003).

Teori kemagnetan dapat dibagi dalam beberapa macam (Telford et al, 1990) diantaranya yaitu :

a) Gaya Magnetik

Gaya magnetik diberi symbol $\overrightarrow{\boldsymbol{F}}$, yang rumusnya berasal dari hukum Coulomb yang mirip dengan hukum Newton, yaitu:

$$
\vec{F}=\frac{m_{1} m_{2}}{\mu_{0} r^{2}} \overrightarrow{\boldsymbol{r}}
$$

b) Kuat Medan Magnet

Simbol dari kuat medan magnet adalah $\overrightarrow{\boldsymbol{H}}$. Bila sebuah titik berada dalam jarak $\boldsymbol{r}$ dan kutub $\boldsymbol{m}$, kuat medan magnetik pada titik tersebut $\overrightarrow{\boldsymbol{H}}$ didefinisikan sebagai gaya pada satu satuan kutub magnetik:

$$
\vec{H}=\frac{\vec{F}}{m_{2}}=\frac{m_{1}}{\mu_{0} r^{2}} \overrightarrow{\boldsymbol{r}}
$$


$\boldsymbol{m}_{2}$ tidak cukup besar pengaruhnya terhadap $\overrightarrow{\boldsymbol{H}}$ yang ada pada titik pengukuran di karenakan $\boldsymbol{m}_{\mathbf{2}} \ll$ $\boldsymbol{m}_{\mathbf{1}} \cdot \boldsymbol{m}_{\mathbf{2}}$ adalah suatu kutub fiktif di udara (instrument).

c) Intensitas Magnetisasi

Intensitas magnetisasi diberi simbol $\overrightarrow{\boldsymbol{I}}$. Suatu kutub magnetik yang diletakan dalam suatu medan magnet akan dimagnetisasi oleh pengaruh imbasnya. Besar intensitas magnetisasi sebanding dengan kuat medan, arahnya sesuai dengan arah medan magnet tersebut. Besaran ini didefinisikan pula sebagai momen magnetik persatuan volume, yaitu:

$$
\vec{I}=\frac{\vec{M}}{V}=\vec{I} \vec{x}_{1}
$$

Magnetisasi imbas menyebabkan dwikutub material magnet penyearah. Maka $\overrightarrow{\boldsymbol{I}}$ sering juga dinamakan sebagai polarisasi magnetik. Bila $\overrightarrow{\boldsymbol{I}}$ konstan dan mempunyai arah yang sama dimanamana, maka tubuh magnetik tersebut dikatakan termagnetisasi secara uniform.

Suseptibilitas kemagnetan diberi simbol $\boldsymbol{k}$ derajat benda termagnetisasi ditentukan oleh besaran yang dinamakan suseptibilitas magnetik $\boldsymbol{k}$, yang didefinisikan sebagai:

$$
k=\frac{\vec{I}}{H}
$$

Respon kuantitatif data geomagnet sangat ditentukan oleh komposisi mineral-mineral yang bersifat magnetik dari pada batuan. Harga $\boldsymbol{k}$ semakin besar bila jumlah mineralmineral magnetik semakin banyak. Harga suseptibilitas untuk beberapa jenis batuan dan mineral dapat dilihat pada Tabel 1 Nilai suseptibilitas beberapa jenis mineral dan batuan sedimen (Telford et al, 1990).

Tabel 1 Nilai suseptibilitas beberapa jenis

\begin{tabular}{|c|c|c|}
\hline Batuan/fineral & $\begin{array}{c}\mathrm{k}\left(10^{-5} \mathrm{SI}\right) \\
\text { (Persatuan Volume) }\end{array}$ & $\begin{array}{c}\chi\left(10^{-5} \mathrm{~m}^{\mathrm{l}} \mathrm{kg}^{-1}\right) \\
\text { (Persatuan Massa) }\end{array}$ \\
\hline \multicolumn{3}{|l|}{ Batuan Bela } \\
\hline Basal & $250-180.000$ & $8.4-6,100$ \\
\hline Diabase & $1.000-160.000$ & $35-5.600$ \\
\hline Gabro & $1.000-90.000$ & $26-3.000$ \\
\hline Granit & $0-50.000$ & $0-1900$ \\
\hline Porpini & $250-210.000$ & $9.2-7.700$ \\
\hline Rhyolite & $250-38.000$ & $10-1500$ \\
\hline Battann Sedimen & \multicolumn{2}{|c|}{ Suseptibilitas (10 $\left.10^{3} \mathrm{Si}\right)$} \\
\hline & \multicolumn{2}{|c|}{ Interral } \\
\hline Dolonite & $0.0,9$ & $0,000-0,0009$ \\
\hline $\begin{array}{l}\text { Limestones (Batu Gamping } \\
\text { Bats Kapur) }\end{array}$ & 0.3 & $0,000-0,003$ \\
\hline Sandstones (Batu Pasir) & 20 & $0,000-0,020$ \\
\hline Stales (Serpih) & $0,01-0,15$ & $0,00001-0,015$ \\
\hline Clay (Lempung) & $0-2$ & $0,000-0,002$ \\
\hline
\end{tabular}
mineral dan batuan sedimen.

Sumber: Telford et al, 1990.

Secara garis besar anomali medan magnetik disebabkan oleh medan magnetik remanen dan medan magnetik induksi. Medan magnet remanen mempunyai peranan yang besar terhadap magnetisasi batuan yaitu pada besar dan arah medan magnetiknya serta berkaitan dengan peristiwa kemagnetan sebelumnya sehingga sangat rumit untuk diamati. Anomali yang diperoleh dari survei merupakan hasil gabungan medan magnetik remanen dan induksi, bila arah medan magnetik remanen 
sama dengan arah medan magnet induksi maka anomalinya bertambah besar. Demikian pula sebaliknya, dalam survei magnetik efek medan remanen akan diabaikan apabila anomali medan magnetik kurang dari $25 \%$ medan magnet utama bumi (Telford et al, 1990).

Untuk memperoleh nilai anomali medan magnetik yang menjadi target survei, maka data medan magnetik yang telah diperoleh harus dibersihkan atau dikoreksi dari pengaruh beberapa medan magnet lain. Secara umum beberapa koreksi yang dilakukan dalam survei magnetik (Telford et al, 1990) meliputi:

a) Koreksi Harian

Koreksi harian (diurnal correction) merupakan penyimpangan nilai medan magnetik bumi akibat adanya perbedaan waktu dan efek radiasi matahari dalam 1 hari. Waktu yang dimaksudkan harus mengacu atau sesuai dengan waktu pengukuran data medan magnetik di setiap titik lokasi (stasiun pengukuran) yang akan dikoreksi. Apabila nilai variasi harian negatif, maka koreksi harian dilakukan dengan cara menambahkan nilai variasi harian yang terekan pada waktu tertentu terhadap data medan magnetik yang akan dikoreksi. Sebaliknya apabila variasi harian bernilai positif, maka koreksinya dilakukan dengan cara mengurangkan nilai variasi harian yang terekam pada waktu tertentu terhadap data medan magnetik yang akan dikoreksi, dapat dituliskan dalam persamaan:

$$
\Delta \boldsymbol{H}=\boldsymbol{H}_{o b s} \pm \boldsymbol{H}_{v h}
$$

\section{b) Koreksi International Geomagnetic} Reference field ( IGRF)

Data hasil pengukuran medan magnetik pada dasarnya adalah konstribusi dari 3 komponen dasar, yaitu medan magnetik utama bumi, medan magnetik luar dan medan anomali. Nilai medan magnetik utama tidak lain adalah nilai $I G R F$. Jika nilai medan magnetik utama dihilangkan dengan koreksi harian, maka kontribusi medan magnetik utama dihilangkan dengan koreksi IGRF. Koreksi IGRF dapat dilakukan dengan cara mengurangkan nilai IGRF terhadap nilai medan magnetik total yang telah terkoreksi harian pada setiap titik pengukuran pada posisi geografis yang sesuai. Persamaan koreksinya (setelah dikoreksi harian) dapat dituliskan sebagai berikut:

$$
\Delta H=H_{o b s}-H_{I G R F} \pm H_{v h}
$$

Pemodelan kedepan 2D (Forward Modeling 2D) adalah pembuatan model melalui pendekatan beradasarkan intuisi geologi, berdasarkan medan magnet pengamatan, medan magnet teori (IGRF), medan magnet harian dapat dilakukan interpetasi berupa pemodelan bawah 
permukaan. Dalam interpetasi geofisika dicari suatu model yang menghasilkan respon yang cocok dengan data pengamatan.Dengan demikian model tersebut mewakili kondisi bawah permukaan (Deniyatno, 2010).

Pemodelan kedepan (forward Modeling) data magnetik dilakukan dengan benda anomali dengan geometri dan harga kemagnetan tertentu. Untuk memperoleh kesesuaian antara data teoritis (respon model) dengan data lapangan dapat dilakukan dengan proses coba-coba (trial and error) dengan mengubah harga parameter model (Deniyatno, 2010).

\section{BAHAN DAN METODE}

Area Situs Megalitik Tadulako yang berlokasi di Desa Doda, Kecamatan Lore Tengah, Kabupaten Poso. Secara letak Geografisnya berada pada $01^{0} 42^{\prime} 30^{\prime \prime}-01^{0}$ $43^{\prime} 00^{\prime \prime}$ LS dan $120^{\circ} \quad 15^{\prime} 00^{\prime \prime}-120^{\circ}$ 16’00"BT (Gambar 2)

Penelitian ini menggunakan peralatan dan bahan utama yaitu Dua set Proton Precision Magnetometer merk GS 19T, jam, GPS, kompas geologi, alat tulis menulis, Software Microsoft Exel 2016, Software Surfer 11, Software Arcgis, dan Software Geosoft.

Prosedur pengambilan data dilakukan dengan 3 tahap yaitu survei pendahuluan, pengukuran base station, dan pengukuran mobile station. Data hasil pengukuran base station berupa data intensitas medan magnet terukur terhadap waktu. Data hasil pengukuran mobile station berupa data intensitas medan magnet terukur terhadap jarak yaitu data posisi (lintang, bujur dan elevasi setiap titik lokasi pengukuran yang telah ditentukan dan waktu setiap pengukuran.

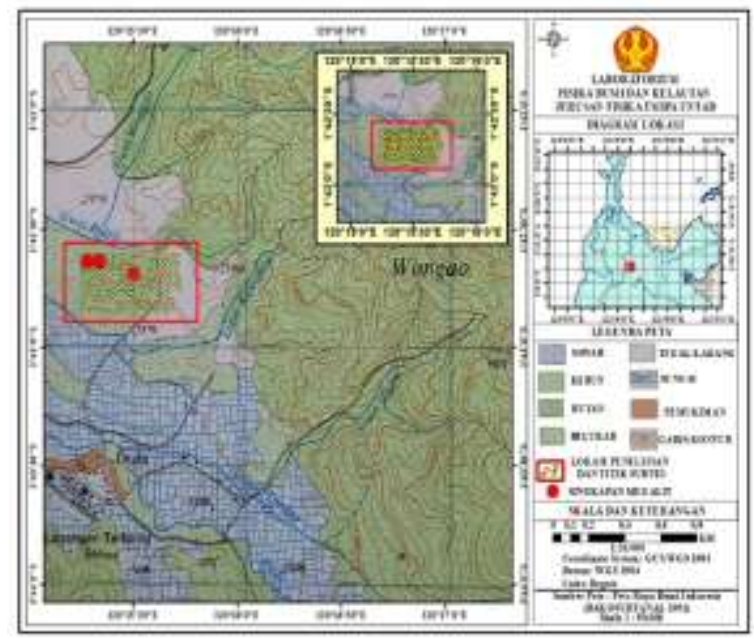

Gambar 2 Peta RBI Lokasi Penelitian

Data yang diperoleh dari pengukuran di lapangan, selanjutnya dilakukan pengolahan dengan langkah-langkah sebagai berikut:

1. Membuat grafik medan magnetik harian di base terhadap waktu dengan menggunakan Software Microsoft Office Excel 2016.

2. Mencari nilai koreksi harian $\left(H_{v h}\right)$ dengan menggurangkan medan magnet bacaan base dengan nilai rata-rata medan magnet bacaan base setelah itu membuat grafik koreksi harian terhadap waktu. Dari grafik tersebut diperoleh persamaan garisnya. Koreksi variasi 
harian dilakukan untuk menghilangkan pengaruh medan magnet luar.

3. Melakukan Koreksi (IGRF) untuk menghilangkan pengaruh dari medan magnet utama bumi dengan mengakses situs $\quad \underline{\quad w d . k u g i . k y o t o-u . a c . j p / c g i-}$ $\underline{\text { bin/point-cgi }}$

4. Menghitung data anomali magnetik total $(\Delta \boldsymbol{H})$ dengan persamaan (6)

5. Langkah selanjutnya adalah membuat peta anomali medan magnet total $\left(\Delta \boldsymbol{T}_{\text {total }}\right)$ dengan menggunakan software Surfer 11 .

6. Membuat model struktur bawah permukaan menggunakan software GMSYS. Input data yaitu data jarak, elevasi, dan anomali magnetik total.

7. Berdasarkan model struktur bawah permukaan menggunakan software GMSYS tersebut diperoleh lapisan batuan penyusun megalit dan diinterpretasikan berdasarkan nilai suseptibilitas batuan dan sesuai kondisi geologi lokasi penelitian

\section{HASIL DAN PEMBAHASAN}

Pada penelitian ini dilakukan identifikasi pada peta kontur anomali total medan magnet dengan hasil yang diperoleh berupa lokasi keberadaan batuan megalit yang menyebabkan timbulnya anomaly (Gambar 3). Survei geomagnet menunjukkan batuan penyusun megalit yang berada di bawah permukan berdasarkan nilai anomali magnetik tinggi yang terdeteksi pada lokasi penelitian dan melakukan pemodelan sebaran batuan penyusun megalit berdasarkan nilai suseptibilitas batuan. Adanya perbedaan nilai anomali magnetik pada setiap titik pengukuran merupakan suatu bentuk penyimpangan akibat pengaruh sifat magnetik material yang menyusun suatu batuan, utamanya yang berada dekat dengan permukaan. Berdasarkan pengukuran geomagnet serta data anomali magnetik yang diperoleh maka dilakukan interpretasi dan pemodelan secara 2D.

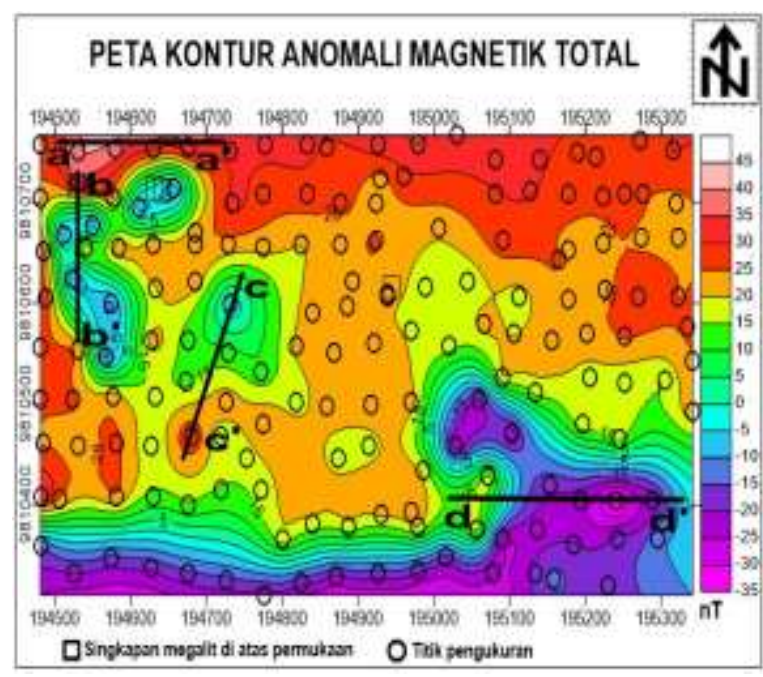

Gambar 3 Peta Kontur Anomali Magnetik Total

Sebelum melakukan pemodelan yang dilakukan pada software GM-SYS ada beberapa hal yang perlu dilakukan yaitu memasukan parameter berupa data hasil slice dari software Surfer 11 berupa interval jarak, elevasi, dan nilai intensitas magnetik dari setiap lintasan. Interval jarak yang digunakan dari setiap lintasan yaitu $9 \mathrm{~m}$, 
nilai ketinggian (elevasi) maksimumminimum dari setiap lintasan yaitu 12331204 mdpl, dan nilai intensitas magnetik maksimum-minimum dari setiap lintasan yaitu 41-(-34) nT. Luas lokasi penelitian berkisar $800 \times 400 \quad \mathrm{~m}^{\wedge} 2$ dengan menggunakan interval jarak $9 \mathrm{~m}$ sehingga didapatkan hasil yang lebih akurat. Setelah itu, memasukan nilai inklinasi dan deklinasi daerah lokasi penelitian, nilai kedalaman maksimum yang akan diinterpretasi, dan nilai IGRF daerah penelitian . Nilai inklinasi dan deklinasi untuk seluruh daerah penelitian dianggap sama yaitu, masing-masing $-19,3110$ dan 0,5850 . Nilai maksimum kedalaman yang digunakan pada setiap lintasan adalah sama yaitu 250 m bmt atau sama dengan $992 \mathrm{~m}$ dpl dari ketinggian maksimum lokasi penelitian yaitu $1250 \mathrm{~m} \mathrm{dpl}$.

Penampang (model) dibentuk sedemikian rupa agar bisa menggambarkan keberadaaan batuan megalit terpendam dan keadaan geologi daerah penelitian dengan merubah bentuk-bentuk benda, posisi, dan suseptibilitas benda. Penampang yang telah dibuat akan menghasilkan kurva hasil pemodelan yang kemudian kurva tersebut harus dibuat menyerupai kurva nilai anomali magnetik dan tingkat errornya kecil maka pemodelan dianggap telah benar. Pada Gambar 4 sampai Gambar 7 kurva dengan garis tidak putus-putus menunjukan kurva hasil pemodelan sedangkan kurva dengan garis putus-putus menunjukan kurva hasil pengukuran (perhitungan). Interpretasi dan pemodelan dilakukan untuk memberikan gambaran bawah permukaan dan menjelaskan posisi dan kedalaman keberadaan batuan megalit. Hal ini dilakukan dengan mengacu sesuai pada literatur yaitu nilai suseptibilitas batuan (Tabel 1).

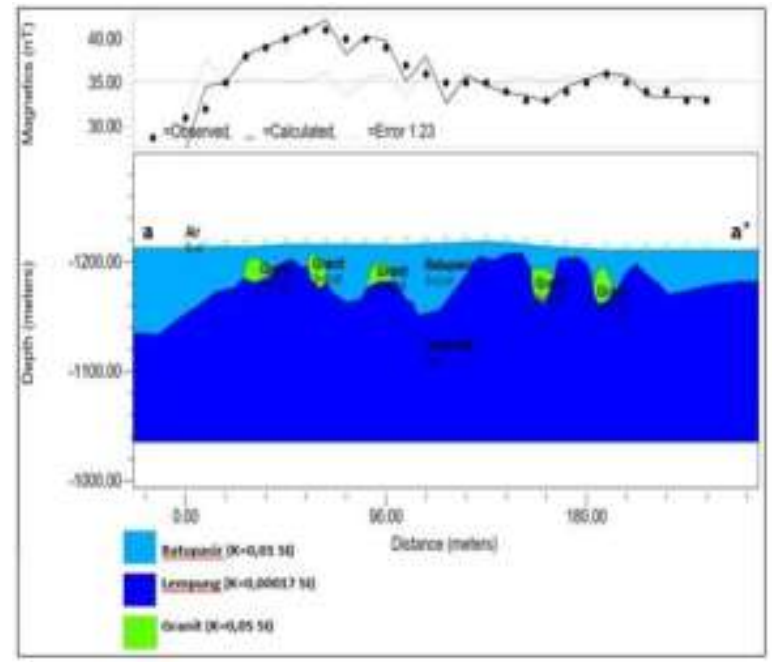

Gambar 4 Model 2D Bawah Permukaan Pada Lintasan a-a'

Pada Lintasan a-a' (Gambar 4) berada pada arah Barat Laut (194502,5688 LS 9810761,497 BT sampai 194721,6152 LS 9810761,497 BT) menunjukkan model bawah permukaan yang tersusun dari beberapa jenis batuan yaitu batupasir dan lempung yang masing-masing dengan nilai suseptibilitas 0,01 SI dan 0,00017 SI dengan panjang lintasan $234 \mathrm{~m}$ dan kedalaman maksimum $250 \mathrm{~m}$ bmt . Selain itu terdapat 5 model batuan yang diinterpretasikan sebagai batuan beku dengan bentuk yang berbeda-beda, dengan 
nilai suseptibilitas 0,05 SI yang berada pada posisi 194524,7653 LS 9810761,497 BT sampai 194689,869 LS 9810761,497 BT dengan kedalaman 1208-1160 m dpl atau sama dengan 11-59 m bmt, pemodelan tersebut disesuaikan berdasarkan literatur dengan mencocokan nilai suseptibilitas batuan (Telford et al, 1990) sehingga batuan-batuan tersebut diinterpretasikan sebagai batuan beku granit yang diduga sebagai batuan megalit.

Pada Lintasan b-b' (Gambar 5) berada pada arah Barat Laut (194531,0047 LS 9810730,566 BT sampai 194531,0047 LS 9810562,325 BT) menunjukkan model bawah permukaan yang tersusun dari beberapa jenis batuan yaitu batupasir dan lempung yang masing-masing dengan nilai suseptibilitas 0,01 SI dan 0,00017 SI dengan panjang lintasan $180 \mathrm{~m}$ dan kedalaman maksimum $250 \mathrm{~m}$ bmt. Selain itu terdapat 1 model batuan yang diinterpretasikan sebagai batuan beku dengan nilai suseptibilitas 0,05 SI yang sesuai dengan literatur penelitian terdahulu oleh Daepawala. M.T (2018, yang berada pada posisi 194530,4518 LS 9810722,264 BT dengan kedalaman 1184-1144 m dpl atau sama dengan 32-72 $\mathrm{m}$ bmt dengan bentuk yang tidak beraturan sehingga diinterpretasikan sebagai batuan beku granit yang diduga sebagai batuan megalit.

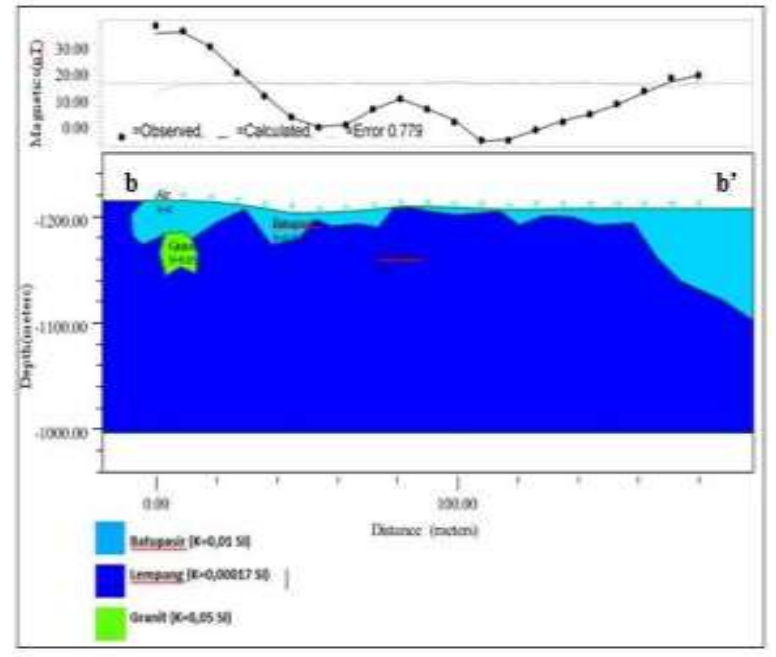

Gambar 5 Model 2D Bawah Permukaan Pada Lintasan b-b'

Pada Lintasan c-c' (Gambar 6) berada pada arah Barat (194748,6 LS 9810630 BT $\begin{array}{lllll}\text { sampai } 194668,8 & \text { LS } 9810446 & \text { BT) }\end{array}$ menunjukkan model bawah permukaan yang tersusun dari 2 jenis batuan yaitu batupasir dan lempung yang masingmasing dengan nilai suseptibilitas 0,01 SI dan 0,00017 SI dengan panjang lintasan $279 \mathrm{~m}$ dan kedalaman maksimum $250 \mathrm{~m}$ bmt. Selain itu terdapat 4 model batuan yang diinterpretasikan sebagai batuan beku granit dengan bentuk yang berbeda-beda, dengan nilai suseptibilitas 0,05 SI yang berada pada posisi 194693,7219 LS 9810503,371 BT sampai 194668,7886 LS 9810445,571 BT dengan kedalaman 1211$1162 \mathrm{~m}$ dpl atau sama dengan 14-63 m bmt dengan nilai error yang kecil yaitu 1,366, hal ini sesuai dengan literatur penelitian terdahulu menurut Yusuf. M (2017) yang menginterpretasikan batuan granit dengan nilai suseptibilitas 0,00 SI - 0,05 SI, 
sehingga diinterpretasikan batuan-batuan tersebut merupakan batuan beku granit yang diduga sebagai batuan megalit.

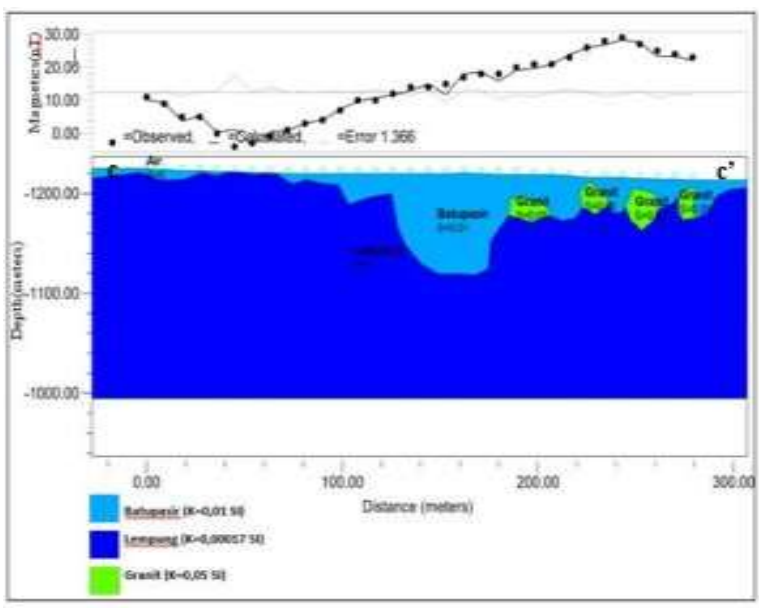

Gambar 6 Model 2D Bawah Permukaan Pada Lintasan c-c'

Pada Lintasan d-d' (Gambar 7) berada pada arah Tenggara (195018,2 LS 9810407 BT sampai 195329,8 LS 9810405 BT) menunjukkan model bawah permukaan yang tersusun dari beberapa jenis batuan yaitu batupasir dan lempung yang masingmasing dengan nilai suseptibilitas $0,01 \mathrm{SI}$ dan 0,00017 SI dengan panjang lintasan $333 \mathrm{~m}$ dan kedalaman maksimum $250 \mathrm{~m}$ bmt. Selain itu terdapat 6 model batuan yang diinterpretasikan sebagai batuan beku granit dengan nilai suseptibilitas 0,05 SI yang sesuai dengan literatur penelitian terdahulu oleh Daepawala. M.T (2018, yang berada pada posisi 195018,2224 LS 9810406,851 BT sampai 195124,3522 LS 9810406,1 BT dengan kedalaman 1219$1176 \mathrm{~m}$ dpl atau sama dengan $12-55 \mathrm{~m}$ bmt dengan bentuk yang tidak beraturan sehingga diinterpretasikan sebagai batuan beku granit yang diduga sebagai batuan megalit.

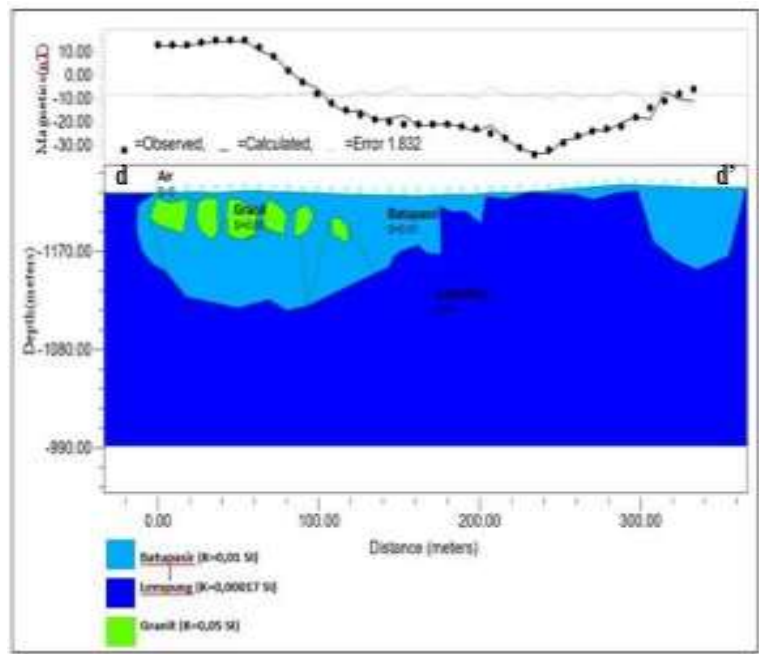

Gambar 7 Model 2D Bawah Permukaan Pada Lintasan d-d'

Berdasarkan hasil pemodelan yang telah dilakukan tampak nilai suseptibilitas yang berbeda-beda dan masing-masing ditunjukan pada Tabel 2.

Dari hasil interpretasi diperoleh batuan penyusun daerah penelitan yang didominasi oleh batuan sedimen, hal ini menunjukkan kesesuaian dengan kondisi geologi daerah penelitian dimana batuan penyusun daerah tersebut adalah Endapan Danau yang terdiri dari batuan sedimen yaitu lempung, lanau, pasir, dan kerikil yang merupakan batuan sedimen. Teridentifikasinya batuan granit di sekitar titik lokasi penelitian diduga sebagai batuan megalit. 
Tabel 2 Interpretasi jenis batuan berdasarkan nilai suseptibilitas batuan (Telford et al, 1990).

\begin{tabular}{|c|c|c|c|c|}
\hline \multirow{2}{*}{ No } & \multicolumn{2}{|c|}{ Nilai suseptibilitas (Si) } & Interpretasi & \multirow{2}{*}{ Keterangan } \\
\hline & Benda & Literatur & Batuan & \\
\hline \multicolumn{5}{|c|}{ Lintasan $2-a^{\prime}$} \\
\hline 1 & 0,01 & $0-0,02$ & Bats Pasir & Batuan Sedimen \\
\hline 2 & 0,00017 & $0,00017-0,0025$ & Lempung & Batuan Sedimen \\
\hline 3 & 0,05 & $0.0,05$ & Granit & Batuan Belus \\
\hline 4 & 0,05 & $0-0,05$ & Granit & Batuan Belas \\
\hline 5 & 0,05 & $0,0,05$ & Granit & Batuan Belal \\
\hline 6 & 0,05 & $0-0,05$ & Granit & Batuan Belus \\
\hline 7 & 0,05 & $0-0,05$ & Granit & Batuan Belas \\
\hline \multicolumn{5}{|c|}{ Lintasen $b-b^{7}$} \\
\hline 1 & 0,01 & $0.0,02$ & Bats Pasir & Batuan Sedimen \\
\hline 2 & 0,00017 & $0,00017-0,0025$ & Lempong & Batuan Sedimen \\
\hline 3 & 0,05 & $0-0,05$ & Granit & Batuan Belas \\
\hline \multicolumn{5}{|c|}{ Iintasan c-c' } \\
\hline 1 & 0,01 & $0-0,02$ & Batu Pasir & Batuan Sedimen \\
\hline 2 & 0,00017 & $0,00017-0,0025$ & Lempung & Batuan Sedimen \\
\hline 3 & 0,05 & $0-0,05$ & Granit & Batuan Belus \\
\hline 4 & 0,05 & $0-0,05$ & Granit & Batuan Belus \\
\hline 5 & 0,05 & $0-0,05$ & Granit & Batuan Belis \\
\hline 6 & 0,05 & $0-0,05$ & Granit & Bahuan Belss \\
\hline \multicolumn{5}{|c|}{ Lintasen $d-d^{d}$} \\
\hline 1 & 0,01 & $0-0,02$ & Batu Pasir & Batuan Sedimen \\
\hline 2 & 0,00017 & $0,00017-0,0025$ & Lempung & Batuan Sedimen \\
\hline 3 & 0,05 & $0-0,05$ & Granit & Batuan Bekss \\
\hline 4 & 0,05 & $0-0,05$ & Granit & Batuan Belss \\
\hline 5 & 0,05 & $0-0,05$ & Granit & Batuan Bekso \\
\hline 6 & 0,05 & $0.0,05$ & Granit & Batuan Belas \\
\hline 7 & 0,05 & $0-0,05$ & Granit & Batuan Beks \\
\hline 8 & 0,05 & $0-0,05$ & Granit & Batuan Belus \\
\hline
\end{tabular}

Menurut literatur bahwa batuan penyusun batuan megalit di Situs Megalitik Tadulako adalah batuan beku yakni granit (Swastikawati, dkk., 2014). Berdasarkan interpretasi yang dilakukan pada ke 4 lintasan terdapat batuan granit pada posisi 194524,7653 LS 9810761,497 BT sampai 194689,869 LS 9810761,497 BT dengan kedalaman 11-59 m bmt (lintasan a-a'), 194530,4518 LS 9810722,264 BT dengan kedalaman 32-72 m bmt (lintasan b-b'), 194693,7219 LS 9810503,371 BT sampai 194668,7886 LS 9810445,571 BT dengan kedalaman 14-63 m bmt (lintasan c-c'), dan
195018,2224 LS 9810406,851 BT sampai 195124,3522 LS 9810406,1 BT dengan kedalaman 12-55 m bmt (lintasan d-d'), dengan nilai eror $1,23 \%-1,832 \%$, sehingga diidentifikasi keberadaan batuan megalit dekat dengan permukaan karena kemungkinan yang menyebabkan batuan tersebut terpendam adalah faktor longsor, banjir, dan tenaga endogen. Oleh karena itu pada lintasan-lintasan tersebut diduga masih terdapat batuan megalit yang terpendam di bawah permukaan tanah.

\section{UCAPAN TERIMAKASIH}

Trimakasih kepada Jurusan Fisika FMIPA UNTAD yang sudah memfasilitasi dalam peminjaman alat penyelesaian tugas akhir ini. Trimakasih juga buat temanteman, kakak-kakak senior, dan adik-adik junior di jurusan Fisika FMIPA UNTAD yang sudah membantu dalam penelitian ini

\section{DAFTAR PUSTAKA}

Baso, A. D. (2013). Identifikasi BendaBenda Megalitik Di Situs Megalitik Pokekea Kecamatan Lore Tengah Kabupaten Poso Dengan Menggunakan Metode Geolistrik. Skripsi Jurusan Fisika FMPA UNTAD. Palu.

Daepawala, M.T. (2018) Pemodelan Benda-Benda Megalit Bawah Permukaan menggunakan Data Geomagnet Di Taman Wisata Palindo Kecamatan Lore Barat Kabupaten Poso. Skripsi Jurusan Fisika FMPA UNTAD. Palu. 
Deniyatno. (2010). Pemodelan kedepan (Forward Modeling) 2 Dimensi Data magnetiK untuk identifikasi biji besi di lokasi X, Provinsi Sumatra Barat. Kendari, Sulawesi Tenggara.

Samantho, A. Y. (2011). Peradaban Atlantis Nusantara . Jakarta Selatan: PT. Ufuk Publishing House.

Simanjuntak, T. O., Surono., dan Supandjonu, J. B. (1997). Peta Geologi Lembar Poso. Sulawesi.

Soemantri, D. P. (2003). Laporan Kuliah Lapangan Geofisika, Laboratorium Alam Karang Sambung, Kebumen, Jawa Tengah.

Swastikawati, A., Arif, G., Yudhi, A. (2014). Kajian Konservasi Tinggalan Megalitik di Lore, Sulawesi Tengah. Jurnal Konservasi Cagar Budaya Borobudur, 8(1), 17-37.

Telford, W. M., Sheriff, R. E., and Geldart, L. P. (1990). Applied Geophysics, $2^{\text {nd }}$ Edition. Cambridge: Cambridge University Press.

Yusuf, M. (2017). Identifikasi BendaBenda Megalit Dengan Menggunakan Metode Geomagnet di Situs Pokekea Kecamatan Lore Tengah Kabupaten Poso. Skripsi Jurusan Fisika FMPA UNTAD. Palu. 